\title{
Flux of Dissolved Organic and Inorganic Constituents in Forested Headwater Streams
}

\author{
Byoung-Koo Choi ${ }^{*}$, Clay N. Mangum", Jeffery A. Hatten ${ }^{2)}$, \\ Janet C. Dewey ${ }^{3)}$, Ying Ouyang ${ }^{4)}$ \\ Research Center for River Flow Impingement and Debris Flow, Gangneung-Wonju National University, \\ Gangneung 210-702, Korea \\ ${ }^{1)}$ Department of Forestry, Mississippi State University, Mississippi State, MS 39762, USA \\ ${ }^{2)}$ Department of Forest Engineering, Resources \& Management, Oregon State University, Corvallis, OR 97331, USA \\ ${ }^{3)}$ Department of Geology and Geophysics, University of Wyoming, Laramie, WY 82071, USA \\ ${ }^{4)}$ USDA Forest Service, 100 Stone Blvd., Mississippi State, MS 39762, USA
}

(Manuscript received 31 August, 2012; revised 2 October, 2012; accepted 22 October, 2012)

\begin{abstract}
Headwaters initiate material export to downstream environments. A nested headwater study examined the flux of dissolved constituents and water from a perennial stream and four ephemeral/intermittent streams in the Upper Gulf Coastal Plain of Mississippi. Water was collected during storm and baseflow conditions. Multiple linear regression was used to model constituent concentration and calculate flux. Event was the major source of water discharged from the ephemeral and intermittent streams however, baseflow was the major source for water discharged by the perennial stream during events. The perennial stream had an area weighted average yields of 10.1, 0.01, 1.03, $0.65 \mathrm{~kg} / \mathrm{ha} / \mathrm{yr}$ of DON (dissolved organic nitrogen), $\mathrm{NO}_{3}{ }^{-}-\mathrm{N}, \mathrm{NH}_{4}{ }^{+}-\mathrm{N}$ and $\mathrm{PO}_{4}{ }^{-3}$, respectively while large variabilities existed between the ephemeral and intermittent streams. These findings highlight the importance of headwaters in protecting the low order drainage basins as a key to water quality within perennial streams.
\end{abstract}

Key Words : Headwaters, Flux, Hydrologic event, Hydrogeochemistry, Nutrients, Water quality

\section{Introduction}

Headwaters are the uppermost areas of drainage basins which initiate stream flow and are important components of the river network with regard to non-point sources of constituents (Nadeau and Rains, 2007). These non-point sources dominant riverine fluxes to coastal regions throughout the world (Howarth et al., 1995). Furthermore, headwater streams

\footnotetext{
*Corresponding author : Byoung-Koo Choi, Research Center for River Flow Impingement and Debris Flow, GangneungWonju National University, Gangneung 210-702, Korea Phone: +82-33-640-3037

E-mail: bkchoi@gwnu.ac.kr
}

transport a wide range of material such as nutrients, dissolved organic carbon, aquatic and terrestrial invertebrates to downstream reaches. These materials play key roles in the structure, function, biodiversity and productivity of riverine ecosystems (Wipfli et al., 2007).

Headwater streams are characterized by distinctive geological features (e.g. geologic composition, stratigraphy and aquicludes), hydrological (e.g. surface and ground water flow paths), biological (e.g. microbiota and vegetation) and chemical processes (Nadeau and Rains, 2007; Triska et al., 2007; Gomi et al., 2002). These headwater streams can be ephemeral, intermittent or perennial depending on the channel bottom's 
elevation above the water table in response to storm events. Storms are of particular importance in discharging water and constituents from headwater streams, and the majority $(\sim 90 \%)$ of dissolved and particulate material in headwater streams is exported by surface and subsurface flow during storm events (Marshall and Hall Jr. 2004; Wipfli et al., 2007).

The nitrogen flux in many temperate regions has increased 2 to 20 times from pre-industrial levels as a result of fertilizer use and land use changes. Indeed, dissolved nitrogen and phosphorus transported from managed systems (e.g. predominantly agriculture, but also forestry and urban areas) have led to eutrophication and subsequent hypoxia in the coastal environment (Lopez-Veneroni and Cifuentes, 1994). Keim and Shoenholtz (1999) found that land disturbance adjacent to streams can be a major factor affecting surface water quality in headwaters of Mississippi. Researches conducted in the Upper Gulf Coastal Plain of Mississippi found that harvest activities adhering to BMPs such as streamside management zones (SMZs) in forested headwaters can reduce adverse water quality impacts from non-point source pollution (Keim and Shoenholtz, 1999; Carroll et al., 2004; Choi et al., 2011). However, current forestry best management practices (BMPs) have no harvest regulations on ephemeral streams (Mississippi Forest Commission, 2008). Therefore, it is important to understand the response of the water and constituents within these systems to management disturbances.

This study examined the flux of water and constituents exported from headwater watersheds during important transport events (e.g. storms). The objective of this study was to determine the flux of dissolved constituents in ephemeral and perennial streams to better understand how transport processes differ between perennial and ephemeral streams.

\section{Materials and methods}

\subsection{Site description}

The study site was a small-scale headwater watershed located in the Hilly Gulf Coastal Plain province of the Upper Gulf Coastal Plain of Mississippi, USA (3330'54.35”N, 89²5’49.39”W). The average precipitation for the past 30 years was $1,451 \mathrm{~mm}$ with average winter (December, January and February) temperature of $7^{\circ} \mathrm{C}$ and summer (June, July and August) temperature of $26^{\circ} \mathrm{C}$. Precipitation was distributed fairly evenly throughout the year with $53 \%$ falling between January and May. Short and high intensity storms are common and storm precipitation can exceed $100 \mathrm{~mm}$ per day on occasions. Vegetation on the site was characteristic of overstory vegetation in the Southeastern Mixed Forest Province of the Southeastern U.S. (Bailey, 1983). The majority of the site was side slopes underlain by the Sweatman soil series (fine, mixed, semiactive, thermic Typic Hapludults). The ridge tops were of the Providence series (fine-silty, mixed, active, thermic Oxyaquic Fragiudalfs) while the floodplains were of the Oaklimeter soil series (coarse-silty, mixed, active, thermic Fluvaquentic Dystrudepts).

The ephemeral and intermittent sub-watersheds are nested within the perennial watershed which drains the entire study area (Figure 1). There are a number of intermittent and ephemeral streams within the perennial watershed, 4 of which streams were chosen for examination (Table 1). Within the perennial watershed which drains the entire study area, 4 monitored sub-watersheds have intermittent to ephemeral streams with treatments that are representative of forest management in the Southeastern U.S. The treatments were part of a larger study of the effects of forestry on hydrological function of headwater streams, but were not a focus of this study. However, these treatments represent a range of watershed 
conditions encountered on similar sites in the Upper Gulf Coastal Plain (Choi et al., 2012). The watersheds were harvested in October of 2007 and had 4 different SMZ treatments. UC1 was unharvested reference, and UC2 was clearcut having a SMZ with logging debris in the drainage channel and UC3 was clearcut having a SMZ without logging debris in the drainage channel. UC4 did not have a SMZ and was clearcut. UCP encompassed the ephemeral and intermittent streams' watersheds which included 20.6 ha of ungaged floodplain and ephemeral and intermittent drainages (Fig. 1).

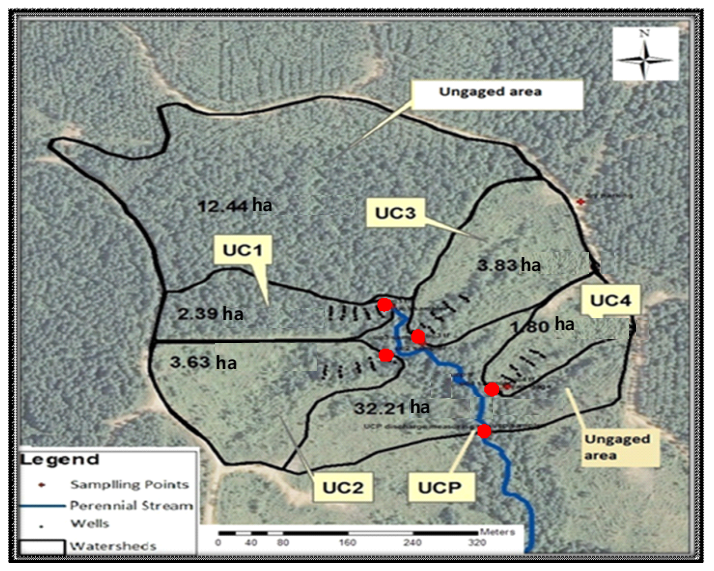

Fig. 1. Map of the study watershed.

\subsection{Streamwater sampling}

Event samples were collected during storm events. Baseflow samples were collected when discharge was at a steady state with very little to no change in the hydrograph. Discharge of the ephemeral and intermittent streams was calculated using velocity sensors (ISCO
750) that recorded water depth and velocity and calculated water discharge. An automatic discrete water sampler (ISCO 2900) was used to collect event water samples. All data were recorded in flowlogger (ISCO 4150) programmed to start sampling during events that meet a discharge or stage threshold. Discharge on the perennial stream was calculated using a stage-discharge rating curve. Stage was measured using a pressure transducer (In-Situ LevelTroll 300) inside a stilling well installed in the center of the perennial stream. The stream profile was measured and rating curve developed from 15 discharge measurements. Velocity and stage data was used to trigger sample collection. Stream monitoring was initiated on all watersheds in February, 2010 and ended in May, 2011. An tipping bucket rain gage (ISCO 674) was located in an open area of UC4 to collect precipitation data.

\subsection{Laboratory analysis}

Samples were filtered through a glass fiber filter (GFF) $0.7 \mu \mathrm{m}$ filter (Whatman 47) and analyzed for dissolved inorganic nitrogen (DIN), dissolved organic nitrogen (DON), nitrate $\left(\mathrm{NO}_{3}{ }^{-}\right)$, phosphate $\left(\mathrm{PO}_{4}^{-3}\right)$ and ammonium $\left(\mathrm{NH}_{4}{ }^{+}\right)$. Constituents $\mathrm{NO}_{3}{ }^{-}$and $\mathrm{NH}_{4}{ }^{+}$ were converted to $\mathrm{NO}_{3}{ }^{-}-\mathrm{N}$ and $\mathrm{NH}_{4}{ }^{+}-\mathrm{N}$. Anions were determined using standard ion chromatography methods (APHA 4110) and cations values were determined using the method (ASTM D6919-09) for dissolved alkali and alkaline earth cations. DIN was calculated as the sum of $\mathrm{NH}_{4}{ }^{+}-\mathrm{N}$ and $\mathrm{NO}_{3}{ }^{-}-\mathrm{N}$. A $9 \mathrm{ml}$ sub-sample was microwave digested in $2 \mathrm{ml}$ of digesting solution containing $3.83 \mathrm{M}$ sulfuric acid

Table 1. Stream class, area, total discharge and maximum discharge in ephemeral, intermittent and perennial watersheds of the study site

\begin{tabular}{ccccc}
\hline Watershed & Stream class & Area (ha) & Total discharge $\left(10^{3} \mathrm{~m}^{3} / \mathrm{yr}\right)$ & Max. discharge $\left(\mathrm{m}^{3} / \mathrm{s}\right)$ \\
\hline \hline UC1 & Intermittent & 2.39 & 27.13 & 0.0007 \\
UC2 & Intermittent & 3.63 & 5.49 & 0.0001 \\
UC3 & Intermittent & 3.83 & 27.79 & 0.0012 \\
UC4 & Ephemeral & 1.80 & 4.99 & 0.0010 \\
Ungaged & Ephemeral & 20.56 & 173.51 & - \\
UCP & Perennial & 32.21 & 239.91 & 0.0473 \\
\hline
\end{tabular}


and $9.23 \mathrm{mM}$ mercuric oxide. The samples were digested using a microwave digestion system (CEM) for an hour at $200^{\circ} \mathrm{C}$ to convert all dissolved nitrogen to $\mathrm{NH}_{4}{ }^{+}-\mathrm{N}$. A wet chemistry analyzer (Technicon Autoanalyzer III) was used to determine total $\mathrm{NH}_{4}{ }^{+}-\mathrm{N}$ (Lo et al., 2005). DON was calculated by the difference of total nitrogen and DIN.

\subsection{Data analysis}

Multiple linear regression with dummy variables was used to define the models of constituent concentration for those periods in which no constituent concentration were available. Precipitation, discharge, time since event, and the rate of change in the discharge were utilized as independent variables. Time since event in the ephemeral streams was defined as any discharge $>0.002 \mathrm{~m}^{3} / \mathrm{s}$ or the rate of change in discharge was $>0.0002 \mathrm{~m}^{3} / \mathrm{s}$ for 15 minutes or stream flow was initiated. A new event was also considered if there was one hour of decline in discharge. Time since event in the perennial streams was defined as any discharge $>0.002 \mathrm{~m}^{3}$. The flux of constituents DON, $\mathrm{NO}_{3}{ }^{-}-\mathrm{N}, \mathrm{NH}_{4}{ }^{+}-\mathrm{N}$ and $\mathrm{PO}_{4}{ }^{-3}$ was calculated every 15 minutes over the entire study period (15 months). Total flux was determined by summing the flux $(\mathrm{kg} / \mathrm{yr})$ for each 15 minute interval and total yield $(\mathrm{kg} / \mathrm{ha} / \mathrm{yr})$ was calculated by dividing the flux by the area of the watershed. Time of concentration (TOC) was calculated as the time from beginning of precipitation to the peak in discharge for each event. Response time was used to detect the time from the beginning of precipitation to the initiation of discharge in ephemeral streams and discharge above baseflow in the intermittent and perennial stream. Response time and TOC was used to examine the effect from storm intensity on the flux of constituents. To determine how each watershed varied, analysis of variance (ANOVA) was used to compare constituent concentrations among watersheds at an $a=0.05$ using Duncan's multiple range test.

\section{Results}

\subsection{Hydrometric observations}

There were many precipitation events but only 16 events generated discharge in one or more of the ephemeral and intermittent streams. Over the 15 month study period, $94 \%$ of the discharge events occurred between January and May while precipitation falling between January and May accounted for 53\%

Table 2. Precipitation characteristics during major events generated discharge in the ephemeral and intermittent streams

\begin{tabular}{clccc}
\hline Event & \multicolumn{1}{c}{ Date } & Event duration $(\mathrm{hr})$ & Max. precipitation intensity $(\mathrm{mm} / \mathrm{hr})$ & Total precipitation (mm) \\
\hline \hline 1 & $20102 / 4$ & 16.75 & 10 & 81 \\
2 & $2010 / 3 / 11$ & 1.75 & 20 & 28 \\
3 & $2010 / 3 / 21$ & 5.75 & 13 & 21 \\
4 & $2010 / 4 / 3$ & 1 & 61 & 18 \\
5 & $2010 / 4 / 23$ & 6.50 & 72 & 110 \\
6 & $2010 / 4 / 30$ & 2.75 & 63 & 61 \\
7 & $2010 / 5 / 2$ & 10.75 & 58 & 66 \\
8 & $2010 / 11 / 29 \sim 30$ & 22.25 & 51 & 61 \\
9 & $2010 / 12 / 31 \sim 2011 / 1 / 1$ & 4.25 & 56 & 82 \\
10 & $2011 / 1 / 25$ & 17.50 & 10 & 38 \\
11 & $2011 / 3 / 8 \sim 9$ & 18.33 & 19 & 58 \\
12 & $2011 / 3 / 14 \sim 16$ & 4 & 20 & 24 \\
13 & $2011 / 4 / 4$ & & 30 & 46 \\
14 & $2011 / 4 / 15$ & 4.75 & 58 & 89 \\
15 & $2011 / 4 / 20 \sim 21$ & 4.25 & 15 & 51 \\
16 & $2011 / 4 / 27$ & 5 & 22 & 41 \\
\hline
\end{tabular}


of the total precipitation. Total precipitation per event was highly variable with an average of $55 \mathrm{~mm}$ (Table 2).

Between January and May, the area became saturated and baseflow occurred due to a high water table and low evapotranspiration early in the growing season. UC1 and UC3 had baseflow from March to April, while UC2 had baseflow between January and March. UC4 had no baseflow over the study period while the perennial stream had water flowing throughout the year.

There was high variability between events and watersheds with respect to discharge and total discharge over events (Table3). There were marked differences between event and baseflow in both stream types. Events made up $72 \%$ of the total discharge in the ephemeral and intermittent streams. In the perennial stream, events only make up $25 \%$ of the total discharge with baseflow making up the remaining $75 \%$. This finding indicates the significance of events in the ephemeral and inttermittent streams of headwater areas. The average time of concentration (TOC) varied from 5.37 to 10.33 hours (Table 3). UC2 had the shortest average TOC and UCP had the longest TOC as expected due to watershed size. The average response time varied from 2.65 to 9.83 hours with UC2 having the shortest response time while UC4 had the longest.

\subsection{Flux of dissolved constituents}

Over the study period, there were 16 storm events but only 12 events were sampled. The events varied in size from large storms which caused almost all stream samplers to collect samples to very small events where fewer samples were collected. Over these events, 232 samples were collected along with 80 baseflow samples over the study period.

Table 4 shows water and constituents yield calculated by modelling constituent concentration and calculate flux using multiple linear regression. The average yield of $\mathrm{NO}_{3}{ }^{-}-\mathrm{N}, \mathrm{NH}_{4}{ }^{+}-\mathrm{N}$, DON and $\mathrm{PO}_{4}^{-3}$ from the ephemeral and intermittent streams was $0.01,1.03,10.09$, and $0.65 \mathrm{~kg} / \mathrm{ha} / \mathrm{yr}$, respectively. From the ephemeral and intermittent streams to the outlet UCP, $\mathrm{NO}_{3}^{-}-\mathrm{N}, \mathrm{DON}, \mathrm{PO}_{4}^{-3}$ flux average decreased slightly while $\mathrm{NH}_{4}{ }^{+}-\mathrm{N}$ increased (Table 4). While there was much variability between the ephemeral streams, the majority of all water and dissolved constituents were exported from the perennial stream, suggesting that there was little processing in the short distance between the ephemeral and perennial streams.

Each watershed behaved differently with regard to constituents and their driving factors. As expected, all constituents at all streams had positive relationships with either total or maximum discharge. However, $\mathrm{NO}_{3}{ }^{-}-\mathrm{N}$ and $\mathrm{NH}_{4}{ }^{+}-\mathrm{N}$ yield of UC4 had a significant

Table 3. Stormflow characteristics during events in ephemeral, intermittent and perennial watersheds of the study site

\begin{tabular}{|c|c|c|c|c|c|c|}
\hline & & $\mathrm{UC1}$ & UC2 & UC3 & UC4 & UCP \\
\hline \multirow{3}{*}{$\begin{array}{c}\text { Event } \\
\text { discharge } \\
\left(\mathrm{m}^{3} / \mathrm{s}\right)\end{array}$} & Mean & 0.00004 & 0.00007 & 0.00073 & 0.00045 & 0.0110 \\
\hline & Min. & 0.00002 & 0.00002 & 0.00001 & 0.00003 & 0.0001 \\
\hline & Max. & 0.00064 & 0.00010 & 0.00012 & 0.00101 & 0.0470 \\
\hline \multirow{3}{*}{$\begin{array}{c}\text { Total } \\
\text { discharge } \\
\left(\mathrm{m}^{3} / \mathrm{s}\right)\end{array}$} & Mean & 0.597 & 0.199 & 1.816 & 0.384 & 4.324 \\
\hline & Min. & 0.057 & 0.024 & 0.030 & 0.012 & 0.306 \\
\hline & Max. & 1.704 & 0.485 & 9.393 & 0.977 & 14.900 \\
\hline \multirow{3}{*}{$\begin{array}{r}\text { TOC } \\
(\mathrm{hr})\end{array}$} & Mean & 6.60 & 5.37 & 7.40 & 8.80 & 10.33 \\
\hline & Min. & 0 & 0.50 & 0 & 0.50 & 0.25 \\
\hline & Max. & 21.50 & 21.50 & 22.75 & 25 & 34 \\
\hline \multirow{3}{*}{$\begin{array}{l}\text { Response time } \\
\text { (hr) }\end{array}$} & Mean & 3.92 & 2.65 & 5.57 & 9.83 & 8.75 \\
\hline & Min. & 0 & 0 & 0 & 0 & 0 \\
\hline & Max. & 8.50 & 3.75 & 19 & 21 & 22 \\
\hline
\end{tabular}


Table 4. Water and constituents yield from the study watershed

\begin{tabular}{|c|c|c|c|c|c|}
\hline \multirow{2}{*}{ Watershed } & \multirow{2}{*}{$\begin{array}{l}\text { Water yield } \\
\left(\mathrm{m}^{3} / \mathrm{ha} / \mathrm{yr}\right)\end{array}$} & $\mathrm{NO}_{3}{ }^{-}-\mathrm{N}$ & $\mathrm{NH}_{4}^{+}-\mathrm{N}$ & DON & $\mathrm{PO}_{4}^{-3}$ \\
\hline & & \multicolumn{4}{|c|}{$\mathrm{kg} / \mathrm{ha} / \mathrm{yr}$} \\
\hline UC1 & 11351 & 0.103 & 0.472 & 8.400 & 1.245 \\
\hline UC2 & 1512 & 0.001 & 0.121 & 0.928 & 0.259 \\
\hline UC3 & 7255 & 0.410 & 1.685 & 52.980 & 1.325 \\
\hline UC4 & 2772 & 2.221 & 0.350 & 5.145 & 0.513 \\
\hline UCP & 7450 & 0.008 & 1.032 & 10.090 & 0.648 \\
\hline
\end{tabular}

negative relationship with response time $(R=-0.557$, -0.573 and -0.540 with $\mathrm{p}=0.031,0.026$ and 0.038 , respectively. Since response time and storm intensity were related, this suggests that lower intensity storms exported less $\mathrm{NO}_{3}{ }^{-}-\mathrm{N}$ and $\mathrm{NH}_{4}{ }^{+}-\mathrm{N}$ from UC4 (Table 3 and 4).

Table 5. Mean constituents concentration by watersheds for event samples collected at the study site

\begin{tabular}{|c|c|c|c|}
\hline Constituent & $\begin{array}{c}\text { Mean } \\
\text { concentration } \\
(\mathrm{mg} / \mathrm{l})\end{array}$ & $\mathrm{N}$ & Watershed \\
\hline & $0.02 \mathrm{c}^{1)}$ & 58 & $\mathrm{UC1}$ \\
\hline $\mathrm{NO}_{3}{ }^{-}-\mathrm{N}$ & $0.15 \mathrm{~b}$ & 80 & $\mathrm{UC} 2$ \\
\hline $\mathrm{P}<0.0001$ & $0.01 \mathrm{c}$ & 14 & UC3 \\
\hline \multirow[t]{3}{*}{$\mathrm{F}=80.42$} & $0.66 \mathrm{a}$ & 38 & UC4 \\
\hline & $0.05 \mathrm{c}$ & 32 & UCP \\
\hline & $1.08 \mathrm{a}$ & 64 & $\mathrm{UC1}$ \\
\hline DON & $0.55 \mathrm{bc}$ & 78 & $\mathrm{UC2}$ \\
\hline $\mathrm{P}<0.0001$ & $1.32 \mathrm{a}$ & 13 & UC3 \\
\hline \multirow[t]{2}{*}{$\mathrm{F}=18.05$} & $0.42 \mathrm{c}$ & 38 & UC4 \\
\hline & $0.77 \mathrm{~b}$ & 27 & UCP \\
\hline & $0.09 \mathrm{a}$ & 56 & $\mathrm{UC2}$ \\
\hline $\mathrm{NH}_{4}^{+}-\mathrm{N}$ & $0.07 \mathrm{a}$ & 31 & UCP \\
\hline $\mathrm{P}<0.3924$ & $0.07 \mathrm{a}$ & 14 & UC3 \\
\hline \multirow[t]{2}{*}{$\mathrm{F}=1.03$} & $0.04 \mathrm{a}$ & 19 & UC4 \\
\hline & $0.04 \mathrm{a}$ & 33 & $\mathrm{UC1}$ \\
\hline & $0.14 \mathrm{a}$ & 6 & $\mathrm{UC} 2$ \\
\hline $\mathrm{PO}_{4}^{-3}$ & $0.07 \mathrm{a}$ & 5 & $\mathrm{UC} 1$ \\
\hline $\mathrm{P}<0.8563$ & $0.04 \mathrm{a}$ & 3 & UC4 \\
\hline \multirow[t]{2}{*}{$\mathrm{F}=0.33$} & $0.04 \mathrm{a}$ & 2 & $\mathrm{UC} 3$ \\
\hline & $0.04 \mathrm{a}$ & 3 & $\mathrm{UCP}$ \\
\hline
\end{tabular}

1) Means with the same letter within the same constituents are not significantly different among watersheds at $a=0.05$ by Duncan's multiple range test.

ANOVA results indicated that $\mathrm{NO}_{3}^{-}-\mathrm{N}$ concentrations from UC4 were higher $(\mathrm{F}=80.42$ and $\mathrm{p}<0.0001)$ than all other watersheds (Table 5). This suggests that the dissolved load is diluted with source water low in dissolved inorganic $\mathrm{N}$ or that the $\mathrm{N}$ is adsorbed or denitrified. DON showed an opposite trend with UC3 and $\mathrm{UC} 1$ being significantly higher than UCP, UC2 and UC4. $\mathrm{NH}_{4}{ }^{+}-\mathrm{N}$ and $\mathrm{PO}_{4}^{-3}$ were not significantly different among the watersheds.

\section{Discussion}

In forested settings, the factor affecting fluxes of dissolved constituents including nitrogen, phosphorus, and carbon include cover crop, fertilizer rates, soil type, slope, climate and implemented BMPs among others. Forestry and urban areas contribute approximately $30 \%$ of the total $\mathrm{N}$ and $\mathrm{P}$ load to the Gulf of Mexico (USEPA, 2009). The median EPA estimates for total nitrogen yield for forested watersheds in the ecoregion which includes the study site is 2.02 $\mathrm{kg} / \mathrm{ha} / \mathrm{yr}$, compared to agricultural pastures have a total nitrogen yield of $4.15 \mathrm{~kg} / \mathrm{ha} / \mathrm{yr}$. This study found nutrient loss from the perennial stream of total nitrogen to be $11.13 \mathrm{~kg} / \mathrm{ha} / \mathrm{yr}$ (Table 4). This value is much higher than the EPA's estimation and flux from agricultural systems. Loss of nitrate from forested areas generally ranges from $<1.0$ to $3.36 \mathrm{~kg} / \mathrm{ha} / \mathrm{yr}$ while agriculture watersheds loss from corn-cropped areas has been found to be as high as $14.5 \mathrm{~kg} / \mathrm{ha} / \mathrm{yr}$ (Schuman et al.,1973). Dissolved organic nitrogen can account for $20 \%$ to $90 \%$ of the total nitrogen load to estuaries (Seitzinger and Sanders, 1997). In this study, we found a much larger DON load of 10.1 
$\mathrm{kg} / \mathrm{ha} / \mathrm{yr}$. A possible reason for this difference was that this study was in a very small headwater while EPA's estimation and the study of Seitzinger and Sanders focused on much larger watersheds and streams. As stream sizes change, in-stream and near-stream processes also change, expecially during strom events. In-stream process such as mineralization of DON to DIN, uptake by organisms and DON changing forms (e.g. DON sorbing onto sediment particles) and changes in near-stream terrestrial sources depending on discharge conditions are all processes that can change the proportion of DON in stream water.

The EPA estimates for phosphorus yield for forested watersheds in the ecoregion which included in the study site is $0.11 \mathrm{~kg} / \mathrm{ha} / \mathrm{yr}$ while agricultural pastures have a total phosphorus yield of 0.13 $\mathrm{kg} / \mathrm{ha} / \mathrm{yr}$. This study found nutrient loss from the perennial stream of $\mathrm{PO}_{4}{ }^{-3}$ to be $0.65 \mathrm{~kg} / \mathrm{ha} / \mathrm{yr}$ that is 5 times higher than the EPA's estimates. Higher loss of $\mathrm{PO}_{4}{ }^{-3}$ found in this study may be attributed to past land uses. The study site experienced forest harvesting in October, 2007 which may affect change in nutrient avaliability (Choi, 2011).

Carroll et al. (2004) conducted the most comparable water quality study. Both studies occurred in north central Mississippi in watersheds with active forest management. However, there were many differences in sampling methods between the studies. Carroll et al. (2004) utilized grab samples that were collected biweekly, syringe filtered and analyzed for dissolved $\mathrm{NO}_{3}{ }^{-}-\mathrm{N}$ and other constituents. Their sample method was limited to baseflow resulting in biased the flux of constituents not by calculating discharge. Thus, their sampling method may led to the $\mathrm{NO}_{3}{ }^{-}-\mathrm{N}$ concentrations of the intermittent and ephemeral streams, and the perennial stream. Additionally, Carroll et al. (2004) focused on dissolved nitrate while our study found that most of all dissolved nitrogen was organic, further underestimating dissolved nitrogen flux from these small streams. These results point to complications not accounted for in previous studies of harvesting effects on water quality. However, it should be noted the $\mathrm{NO}_{3}^{-}-\mathrm{N}$ concentrations in this and the Carroll et al. (2004) study were very low, so it would not amount to a concentration or flux that would approach the magnitude yielded by agricultural systems.

The ephemeral and intermittent streams examined in this study exhibited a wide range of natural variability with regard to flux of dissolved constituents as is expected from low order streams (Carroll et al., 2004). Since $64 \%$ of UCP's watershed had a similar forest stand structure to UC1, these two watersheds may have behaved similarly. UC2 had the lowest flux of all constituents, possibly due to the prevalence of soil pipes within the watershed or the heavy vegetation at the site. At UC3, the streambed was highly channelized possibly affecting chemical flux. At UC4, events were flashier and response time was significantly related to constituent yield. While these watersheds differ from one another, there may be many influences on yield from diffuse sources.

UCP was 11 times larger in size and the average max discharge was 27 times larger than those of sub-watersheds. This suggests that all water entering the perennial from the ephemeral streams during large events is moving out of UCP quickly. This suggests that during events constituents have very little time to be chemically altered. While UCP is 11 times larger than the sub-watersheds, it only produces 6 times more total water discharge on average. This is possibly attributed to the ungaged large forested catchment 12.44 ha having a high evapotranspiration rates reducing the water flux during the less active portions of the hydrograph (i.e. baseflow, falling limb). This indicates that water in the perennial could become more concentrated in constituents than partially harvested sites with less evapotranspiration. 


\section{Conclusion}

This study examined the flux of water and constituents exported from headwater watersheds during important transport events. Precipatation event was the major source of water discharged from the ephemeral and intermittent streams while baseflow discharged from groundwater was the major source for water discharged by the perennial stream during events. The perennial stream had an area weighted average yields of 10.1, $0.01,1.03,0.65 \mathrm{~kg} / \mathrm{ha} / \mathrm{yr}$ of DON, $\mathrm{NO}_{3}{ }^{-}-\mathrm{N}, \mathrm{NH}_{4}{ }^{+}-\mathrm{N}$ and $\mathrm{PO}_{4}^{-3}$, respectively that indicates higher load than would be expected in small streams. Overall, we found minor trends in constituent flux from the ephemeral to the perennial scale suggesting that there is apparently enough time for some chemical alteration. Moreover, there is less water and constituents exiting the perennial stream than would be expected from examining the ephemeral streams and how they represent the area. More research is need to better understand the mechanisms by which water and nutrients are exported from headwater watersheds during storm events, the source of these materials (e.g. water, nutrients) and effects of land use management in the low order drainage basins.

\section{References}

Bailey, R. G., 1983, Delineation of ecosystem regions, Environmental Management , 7, 365-373.

Carroll, G. D., Schoenholtz, S. H., Young, B. W., Dibble, E. D., 2004, Effectiveness of forestry streamside management zones in the sand-clay hills of Mississippi: early indications, Water, Air, and Soil Pollution, Focus 4, 275-296.

Choi, B., 2011, Headwater hydrologic functions in the Upper Gulf Coastal Plain of Mississippi, Ph. D. Dissertation, Mississippi State University, Mississippi, USA.

Choi, B., Dewey, J. C., Hatten, J. A., Ezell, A. W., Fan, Z., 2012, Changes in Vegetative communities and water table dynamics following timber harvesting in small headwater streams, Forest Ecology and Management, 281, 1-11.

Gomi, T., Sidle, R. C., Richardson, J. S., 2002, Understanding processes and downstream linkages of headwater systems, Biosciences, 52, 905-916.

Howarth, R. W., Billen, G., Swaney, D., Townsend, A., Jaworski, N., Lajtha, K., Downing, J. A., Elmgren, R., Caraco, N., Jordan, T., Berendse, F., Freney, J., Kudeyarov, V., Murdoch, P., Zhao-Liang, Z., 1995, Regional nitrogen budgets and riverine $\mathrm{N}$ and $\mathrm{P}$ fluxes for the drainages to the North Atlantic Ocean: Natural and human influences, Biogeochemistry, 35, 75-139.

Keim, R. F., Schoenholtz, S. H., 1999, Functions and effectiveness of silvicultural streamside management zones in loessial bluff forests, Forest Ecology and Management, 118, 197-209.

Lo, K. V., Wong, W. T., Liao, P. H., 2005, Rapid determination of total Kjeldahl nitrogen using microwave digestion, Journal of Environmental Science and Health, 40, 609-615.

Lopez-Veneroni, D., Cifuentes, L. A., 1994, Transport of dissolved organic nitrogen in Mississippi river plume and Texas-Louisiana continental shelf near-surface waters, Estuaries, 17, 796-808.

Marshall, M. C., Hall Jr., R. O., 2004, Hyporheic invertebrates affect $\mathrm{n}$ cycling and respiration in stream sediment microcosms, Journal of the North American Benthological Society, 23(3), 416-428.

Mississippi Forestry Commission, 2008, Mississippi’s Best Management Practices, 4th ed., MFC Publication, No. 107, Mississippi, USA.

Nadeau, T. L., Rains, M. C., 2007, Hydrological connectivity between headwaters streams and downstream waters: How science can inform policy, Journal of the American Water Resources Association, 43(1), 118-133.

Schuman, G. E., Burwell, R. E., Piest, R. F., Spomer, R. G., 1973, Nitrogen losses in surface runoff from agricultural watersheds on Missouri Valley loess, Journal of Environmental Quality, 2(2), 299-302.

Seitzinger, S. P., Sanders, R. W., 1997, Contribution of dissolved organic nitrogen from rivers to estuarine eutrophication, Marine Ecology Progress Series, 159, 1-12. 
Triska, F. J., Duff, J. H., Sheibley, R. W., Jackman, A. P., Avanzino, R. J., 2007, DIN retention- transport through four hydrologically connected zones in a headwater catchment of the Upper Mississippi River, Journal of the American water resources association, 43(1), 60-71.

USEPA, 2009, Agricultural Nonpoint Source Pollution:
Agenda for the Future, Washington D.C., USA

Wipfli, M., Richardson, J., Naiman, R., 2007, Ecological linkages between headwaters and downstream ecosystems: Transport of organic matter, invertebrates, and wood down headwater channels, Journal of the American Water Resources Association, 43(1), 72-85. 